\title{
Indigenous Territoriality: External Discourses and Native Perspectives on the Space Inhabited by Tegria's U'wa Community
}

\section{Territorialidad Indígena: Discursos externos y perspectivas propias del espacio habitado por la comunidad U'wa de Tegría}

Oscar Fernando Gamba-Barón'; Daniel Esteban Unigarro-Caguasango ${ }^{2}$; Nohora Inés Carvajal-Sánchez ${ }^{3}$

'Sociologist, M.Sc. student. Universidad Pedagógica y Tecnológica de Colombia en convenio con el Instituto Geográfico Agustín Codazzi, Bogotá, Colombia; e-mail: oscar.gamba01@uptc.edu.co; (D) https://orcid.org/0000-0003-3499-7702

${ }^{2}$ Political scientist, M.Sc., Ph.D.(c). Universidad de La Salle, Facultad de Ciencias del Hábitat, Bogotá, Colombia; e-mail: dunigarro@unisalle.edu.co; (D) https://orcid.org/0000-0002-6310-0223

${ }^{3}$ Sociolologist, Industrial Engineer, M.Sc., Ph.D. Universidad Pedagógica y Tecnológica de Colombia, Bogotá, Colombia; e-mail: nohora.carvajal@uptc.edu.co; (D) https://orcid.org/0000-0003-3326-3045

How to cite: Gamba-Barón, O.F.; Unigarro-Caguasango, D.E.; Carvajal-Sánchez, N.I. 2021. Indigenous Territoriality: External Discourses and Native Perspectives on the Space Inhabited by Tegria's U'wa Community. Rev. U.D.C.A Act. \& Div. Cient. 24(1):e1621. http://doi. org/10.31910/rudca.v24.n1.2021.1621

Open access article published by Revista U.D.C.A Actualidad \& Divulgación Científica, under Creative Commons License CC BY-NC 4.0

Official publication of the Universidad de Ciencias Aplicadas y Ambientales U.D.C.A, University, Accredited as a High-Quality Institution by the Colombian Ministry of Education

Received: june 30, $2020 \quad$ Accepted: january 26, $2021 \quad$ Edited by: Ingeborg Zenner de Polanía

\begin{abstract}
Tegria's community is part of the U'wa indigenous people, who have inhabited the eastern slope of the Sierra Nevada del Cocuy since the pre-Hispanic period, in the jurisdiction of the current municipality of Cubara in Boyaca (Colombia). However, this region known as Sarare has been described from anthropological, ethnohistorical, linguistical, and to a lesser extent, geographical approaches, which have generated representations of territory that ignore the historical process of indigenous people. To account for the present territoriality, it was proposed to contrast these external discourses with the community's visions on its history of occupation and the transformations of the inhabited space, compiled through participatory methodologies that sought the collaborative
\end{abstract}

construction of knowledge based on joint recognition of the place, the participant observation and the constant dialogue between indigenous and researchers. In this way, it was established that the external discourses show a territory that does not correspond to the processes of appropriation, adaptation, and reconfiguration of the space that the U'wa indigenous community has lived through and are evident in everyday settings such as the cultivation plot and the school. Therefore, it is only possible to recognize indigenous territoriality by exploring other alternatives, expressions, and perspectives that involve directly the communities and are not external to the context of the inquiry itself.

Keywords: U'wa people; Cosmovision; Collective memory; Territorial representations; Indigenous space. 


\section{RESUMEN}

La comunidad de Tegría hace parte del pueblo indígena U'wa, que ha habitado desde el periodo prehispánico la ladera este de la Sierra Nevada del Cocuy, en jurisdicción del actual municipio de Cubará en el departamento de Boyacá. Colombia. Esta región, conocida como el Sarare, ha sido descrita desde enfoques antropológicos, etnohistóricos, lingüísticos y, en menor medida, geográficos, que han generado representaciones del territorio que desconocen el proceso histórico del habitar indígena. Para dar cuenta de la territorialidad presente, se contrastaron estos discursos externos con las perspectivas propias de la comunidad sobre su historia de ocupación y las transformaciones del espacio habitado, recopiladas a través de metodologías participativas que buscaron la construcción colaborativa de conocimiento a partir de la observación participante y un constante diálogo de saberes. De esta forma, se estableció que los discursos externos muestran un territorio que no se corresponde con los procesos de apropiación, adaptación y reconfiguración del espacio que la comunidad indígena U'wa ha vivido y son evidentes en escenarios cotidianos como la chagra -área destinada para cultivos rotativos- y la escuela, por lo que solo es posible reconocer la territorialidad indígena mediante la exploración de otras alternativas, lenguajes y perspectivas que involucren directamente a las comunidades y no resulten ajenas ni extrañas al propio contexto de indagación.

Palabras clave: Pueblo U'wa; Cosmovisión; Saberes propios; Representaciones territoriales; Espacio indígena.

\section{INTRODUCTION}

The U'wa indigenous people have had considerable public recognition since the 1990 s, when they put into practice resistance strategies and actions to vindicate their rights against the pressure exercised by a foreign company with extraction purposes -the Occidental Petroleum Corporation (OXY) - in their ancestral territory, which extended through the jurisdiction of the current departments of Boyacá, Arauca, Norte de Santander, Santander and the neighboring state of Táchira in the Republic of Venezuela (Osborn, 1995). This resistance was considered by environmentalists and Non-Governmental Organizations (NGOs) as a paradigmatic case of the struggles carried out by ethnic groups in defense of their territorial rights. However, the production of documentary sources and academic research (Rochereau, 1914, 1961; Osborn, 1985, 1995; Pradilla, 1978; Falchetti, 2003) focusing on the struggle of the U'wa people for the territory has been discontinuous and has not attempted to understand the forms of appropriation and configuration of the inhabited geographic space produced by the communities themselves.

As a human group, the U'wa belong to the Chibcha linguistic family and have historically inhabited the slopes of the Sierra Nevada del Cocuy, which constitutes the center of their cosmology (Osborn, 1985, 1995). According to ethnohistoric sources, the ancestral U'wa territory extended eastward into to the current jurisdictions of the state of Táchira (Venezuela) and northward, in Colombia, into the municipalities of Chinácota, Málaga, and Bucaramanga; Chiscas, Chita, Salinas de Chita and Güicán in the heart of the Sierra, in the department of Boyacá; and Tame, Támara, and Morcote towards the foothills of the Piedemonte Llanero (Osborn, 1995). At present, the U'wa people live in the eastern mountain range of the Colombian Andes, at the point where it begins to decline into the lowlands of southwestern Venezuela (Osborn, 1995), that is, between the departments of Arauca, Boyacá, Norte de Santander, and Santander (Figure 1).

Although the U'wa people and territory have been studied by the social sciences, especially by anthropology and linguistics, the documentary research showed that explicitly geographical studies are absent. For this reason, an approach to U'wa territoriality was proposed from the perspective of the space inhabited or lived by the communities themselves, which can contrast or differ from the conceptualization made by external agents, especially if it is taken into account that the territory, as an inhabited space, is the result of a process of social construction that develops over time through the appropriation by a community of a specific geographic space (Valenzuela \& Figueroa, 2012). Thus, the territory shows an affective relationship with the space to the extent that it acquires meaning on account of the feelings and symbolisms that are attributed to the places therein (Carvajal, 2011), so that its scope exceeds the simple sphere of a political-administrative jurisdiction to configure itself as a referent of identity, as the receptacle of the memory of a community or, in the words of the U'wa, as the essence of life (Serje, 2011).

In a certain way, this has been recognized by the 1991 Political Constitution of Colombia when it ratifies the special character of legal and socio-political institutions such as reservations [resguardos], which are made up of an indigenous community or group that owns its territory through a community property title and is governed adjusted to their cultural traditions (Riaño, 2003). In this sense, it was sought to understand the territoriality in the U'wa United Indigenous Reservation [Resguardo Indígena Unido U'wa] -established through the Incora Resolution 056 of August 6, 1999, with an area of 220,275 hectares (AsoU'wa, 2014) - and, especially, to analyze in-depth the processes and logics of appropriation of the U'wa people, not only in their cultural and cosmological aspect but also in their productive or socio-economic aspects. To achieve this goal, we worked with one of the seventeen most traditional communities of the U'wa people: the Tegría or Tagrinu'wa, whose lands -approximately 17,819.42ha, according to data obtained from the digitization of the cartography available in the Safeguard Plan of the U'wa People (AsoU'wa, 2014) - are located in the central part of the reservation. This digitization made it possible to establish that in the U'wa spatial order, the sacred communal zone is the area with the largest extension within the United U'wa Reservation, a fact consistent with the cosmological importance that the different communities give to these territories, which are mostly made up of páramo [high moorlands], superpáramo, and glaciers or perpetual snows biomes (Flórez, 1991). In terms of territorial extension, from largest to smallest occupied area, the territory of the Tegria is fourth among the U'wa communities (Table 1). 


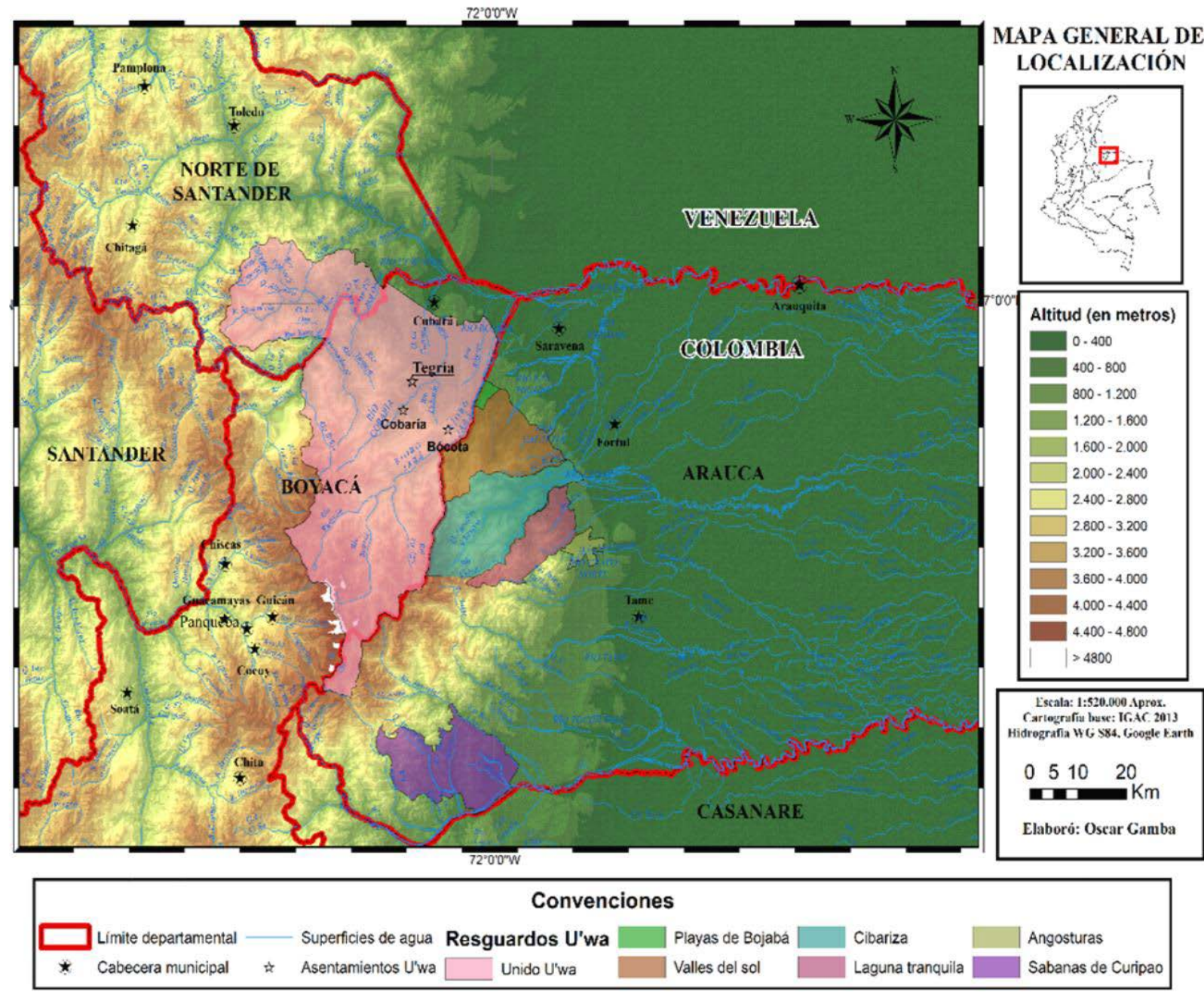

Figure 1. General map with the location of the U'wa United Reservation; the approximate location of some of the most traditional communities (Tegría and Cobaría) is included. Author: Oscar Gamba.

Table 1. Distribution of the territory by communities within the U'wa United Reservation

\begin{tabular}{|c|c|}
\hline Community & Area (ha) \\
\hline Sisuma (Sacred Zone) & $47.327,12$ \\
\hline Aguablanca & $43.624,42$ \\
\hline Bachira & $31.594,85$ \\
\hline Cascajal & $18.526,36$ \\
\hline Tegría & $17.819,42$ \\
\hline Cobaría & $15.063,07$ \\
\hline Bókota & $12.375,55$ \\
\hline Mulera & $9.695,51$ \\
\hline Barrosa & $8.483,57$ \\
\hline Rotarbaría & $4.499,94$ \\
\hline Segovia & $2.814,85$ \\
\hline Rinconada & $2.388,33$ \\
\hline Tamarana & $1.801,40$ \\
\hline Laguna & $1.166,67$ \\
\hline Unkasia & $1.081,99$ \\
\hline
\end{tabular}

Source: Prepared by the author by processing the cartography digitized by the authors through Geographic Information Systems -GIS-. 


\section{MATERIALS AND METHODS}

So as to approach the ancestral territoriality of the U'wa people and, specifically, the dynamics of appropriation and reproduction of space within the Tegría community, this research was divided into two phases: an initial phase focused on the search and documentary review of academic sources and aimed at identifying the discourses generated by anthropologists and linguists, among others; and the second phase of fieldwork, in which different information gathering techniques typical of qualitative research were used, such as ethnography, participative observation, and semi-structured interviews, which sought to promote the collective construction of knowledge through strategies such as workshops with the participation and collaboration of some key actors within the community, such as the ethnic-educators of the indigenous schools of the United U'wa Reservation.

The documentary research phase led to the consolidation of a corpus of texts arising from different academic discourses and areas of expertise, among which those of an anthropological and linguistic nature stand out for their abundance. The analysis of these sources made possible the identification of certain forms of representation of the U'wa territory generated by external agents and linked to a system of concepts, knowledge, and techniques that, due to the particularities of each disciplinary approach, result in the erasing of the perspectives of the communities about the territory they inhabit. Consequently, and to transcend the academic viewpoint, the second phase -fieldwork- was planned, which made possible the collection of primary information through several short stays in the field between 2017 and 2020 .

In methodological terms, ethnography was the starting point for the gathering and co-construction of primary information with some key agents, especially teachers and directors of the indigenous educational centers of 'Tegría's U'wa community. In total, twenty-one teachers from the campuses of the municipality of Cubará (Boyacá) collaborated and participated, under the leadership of the academic coordinator of the El Chuscal Boarding School, Elizabeth Tarazona Cobaría. Thus, instead of establishing a utilitarian relationship between researchers and the community, the work with the educators of the reservation was always based on the principle of horizontality, to generate a type of collective research (Fals Borda, 1999) in which the educators received assistance in the discussion of the concerns and limitations that they identified in their context, that is, their daily pedagogical practices.

Finally, we proceeded to systematize the observations made throughout the process of assisting the teaching team of the United U'wa Reservation in their discussions, which started in 2017, and to contrast, the resulting information with that obtained from the secondary bibliographic sources that were surveyed -particularly the ethnographies about the U'wa people written in the last three decades of the 20th century (Chaves, 1974; Pradilla, 1978; Márquez, 1981; Márquez, 1983; Osborn, 1995)-, with the semi-structured interviews carried out with the teachers during field visits, as well as with the direct and participative observation carried out in the territory.

\section{RESULTS AND DISCUSSION}

The contrast between the external discourses identified in the review of the available documentary sources and the perspectives of the space inhabited by Tegría's U'wa community that were obtained during fieldwork shows a conceptual and epistemological gap in relation to the way in which the indigenous territory is internally conceived and understood, so that it becomes possible to account for the representations generated by external discourses and, subsequently, to reveal U'wa territoriality based on the meaning and sense that space has for the community.

The U'wa Territory from the point of View of External Discourses: The Expert View of Anthropologists and Linguists. The study of indigenous peoples has focused on their forms of social organization, customs, traditional practices, and rituals, in addition to their language as a means of communication and transmission of ancestral thought and knowledge; in other words, academic and scientific production has been generated from anthropology and linguistics in accordance with their methodological approaches. This has not been the exception in the case of the U'wa people, and anthropological, ethnohistoric, and ethnolinguistic research includes a description of the geographic space inhabited by the indigenous peoples as a scenario objectified from a specialized perspective that reproduces a foreign designation, namely, "Tunebo".

In this sense, the ethnohistorical work based on sources from the colonial period reflects the pre-Hispanic presence of the "Tunebo Indians" on the western slope of the Sierra Nevada del Cocuy and their displacement towards the east during the 17th century due to the onslaught of the white encomenderos (Falchetti, 2003). Those who refused to be reduced and managed to evade the "civilizing process" and indoctrination received the pejorative qualification of "infidel Tunebos": non-Christian Indians who inhabited areas not colonized by the Spanish on the eastern slope of the Sierra Nevada (Pradilla, 1978; Falchetti, 2003). During the period of colonial domination, there was a simultaneous process of deterritorialization and reterritorialization around the Sierra by the U'wa people, which led to the occupation of the territory by the different clans in three zones of different altitude, which consequently led to a division into the groups of the low, middle, and high lands (Osborn, 1985; Osborn, 1995; Falchetti, 2003). According to this classification, the Tegría community is a group of the middle lands, since its main ceremonial settlement is located between 1,500 and 2,200m a.s.l.; however, like a considerable number of the other communities, it owns lands in different areas, allowing its members to change their dwelling place throughout the year and revealing periodic migrations as a manifestation of the vertical management of the territory (Márquez, 1983; Osborn, 1995).

Regarding linguistic studies, it is possible to trace back some texts to the colonial period written by Jesuit and Augustinian missionaries who expounded on the "Tunebo language", but the first work that stands out for its ethnological approach to the study of the language was only published in the first part of the 20th century, the research of a Eudist missionary active between 1914 and 1939 
in the indoctrination of the Indians of the Sarare (Rochereau, 1914; Rochereau, 1926; Rochereau, 1961). Decades later, when missionaries of Laura's Mission settled in the region, one of them wrote about the cosmogony of the "Tunebo Indians" (Márquez, 1981; Márquez, 1983) and, years later, together with two members of the Tegría group, published a Grammar of the Tunebo language (Márquez et al. 1988). This work, together with the bilingual TuneboSpanish dictionary published by a Protestant missionary of the Summer Institute of Linguistics (Headland, 1997), constitute the most important contributions related to the language of the U'wa people. It should be noted that the understanding of specific aspects of language such as phonetics and phonology were made possible only by the decades-long contact of the communities and the missionaries, who despite aiming at the acculturation of the former, contributed significantly to the linguistic studies of the Uw'ajka.

Most of these works are the result of an extensive presence in the field by the authors: their long process of relating with the U'wa indigenous communities gave rise to studies with robust theoretical, conceptual and, methodological apparatuses rotted in anthropology and linguistics. Despite, it must be added that the resulting discourses responded to the logic of construction and production of unidirectional and objectifying scientific knowledge, typical of positivist research, which promotes a separation between the researcher and the study object. Therefore, a considerable portion reflects the presence of exotics devices and construction based on rhetoric that conceptualizes ethnicity based on the colonial perspective of figures alien the community itself, who does not acknowledge the academics, researchers, and missionaries as authors. However, it is impossible to ignore their great contribution in relation to the understanding of the cosmogony, language, and ways of inhabiting the territory of the U'wa indigenous people. Indeed, it is worth highlighting the work of Paul Rivet, a renowned French ethnologist who, without living with the U'wa communities directly, but just through the exchange of correspondence with Rochereau, offered one of the first general characterizations of this ethnic group in an anthropological key, presented a grammatical sketch of its language, and built a cartography with the location of the territory occupied by the U'wa and neighboring indigenous peoples (Rivet, 1924).

This is how although the U'wa territory was not conceived as an explicit object of study, it was characterized, defined, and described according to anthropological and linguistic discourses, thus generating a scientific representation thereof. An example of such a representation is the ethnographic description of the Eudist missionary Henri Rochereau (1961), in which, after presenting the mentality, customs, beliefs, traditions, productive activities, items of daily use, and even the plant and animal species of the surroundings, offers a presentation of "the land of the Unkasias" with the "Tunebo names" of the hills, rivers, streams, and sacred places. This is complemented by a map which privileges the location of abiotic elements of the landscape such as hydrography and shows the distribution of the area in seven large U'wa communities located in the current department of Boyacá, specifically the settlements of Sinsiga, Bokota, Tegría, Cobaria, Unkasia, Mojicones, and
Pedraza. In general, this cartographic representation downplays the importance of the most significant cosmogonic and geographic references for the U'wa people: the Sierra Nevada del Cocuy or Sisuma, in the Uw'ajka language, whose name appears at the bottom of the map, following the traditional cartographic convention of locating the geographic north above (Figure 2). In this sense, both the description and the map contribute to the construction of a scientific representation of the U'wa territory that is not only alien and strange in relation to the indigenous people's ways of inhabiting, but also ignores its appropriation logics and organization and representation of the inhabited space, that is, its territorialization process.

However, ethnographic approaches have laid the foundations for the understanding of the meaning of the U'wa territory, not only as a space configured through practices of food production and supply of goods, but as a projection of the ancestral cosmology on the inhabited space, a process that has generated a ritual ecology (Osborn, 1985; Osborn, 1995), so that spatial ordering is directly linked to ritual and cosmogonic aspects, that is, to the symbolic dimension that underpins territoriality as a process of sociocultural appropriation of space (García, 1976). Hence the importance of the super-paramo and perpetual snow areas of the Sierra that are conserved and defended by the communities through a unique environmental management which turns them into a sacred space in which productive activities are not carried out. This view is supported by the law of origin of the U'wa people and is deeply rooted in the life practices of the communities up to the present time (Osborn, 1995, Pradilla, 1978). This becomes evident, for example, in the case of the Tegría community, whose most important of the three main settlements, which functions as a ceremonial center and whose toponym replicates that of the group, is located in the highest zone, close to the communal sacred area and away from the rest of the settlements.

U'wa Territoriality from the Point of View of Native Representations and Knowledge. From the anthropological perspective, an indigenous territory is an essential space for people to access the natural resources that make their material and spiritual reproduction possible in accordance with the characteristics of their productive and social organization (Balza, 2001). This understanding of the territory goes beyond the definition of a geographical space delimited by political-administrative jurisdictions. This broader vision implies the need to make an interpretation of the processes of use, appropriation, and construction of the territory, considering the multiplicity of society-nature and space-time relationships that configure it (Viasús-Figueredo et al. 2016). Consequently, addressing indigenous territoriality implies an understanding that, for an indigenous community, the inhabited place is understood as a territory that is conceived under a native worldview, native insofar as it is both a material expression of social and political order as well as a collective representation of social relations (Correa, 2004).

In this sense, the indigenous territory is ordered according to native precepts emanating from the worldview and the law of origin, by virtue of which the discourse of ancestry acquires great importance 


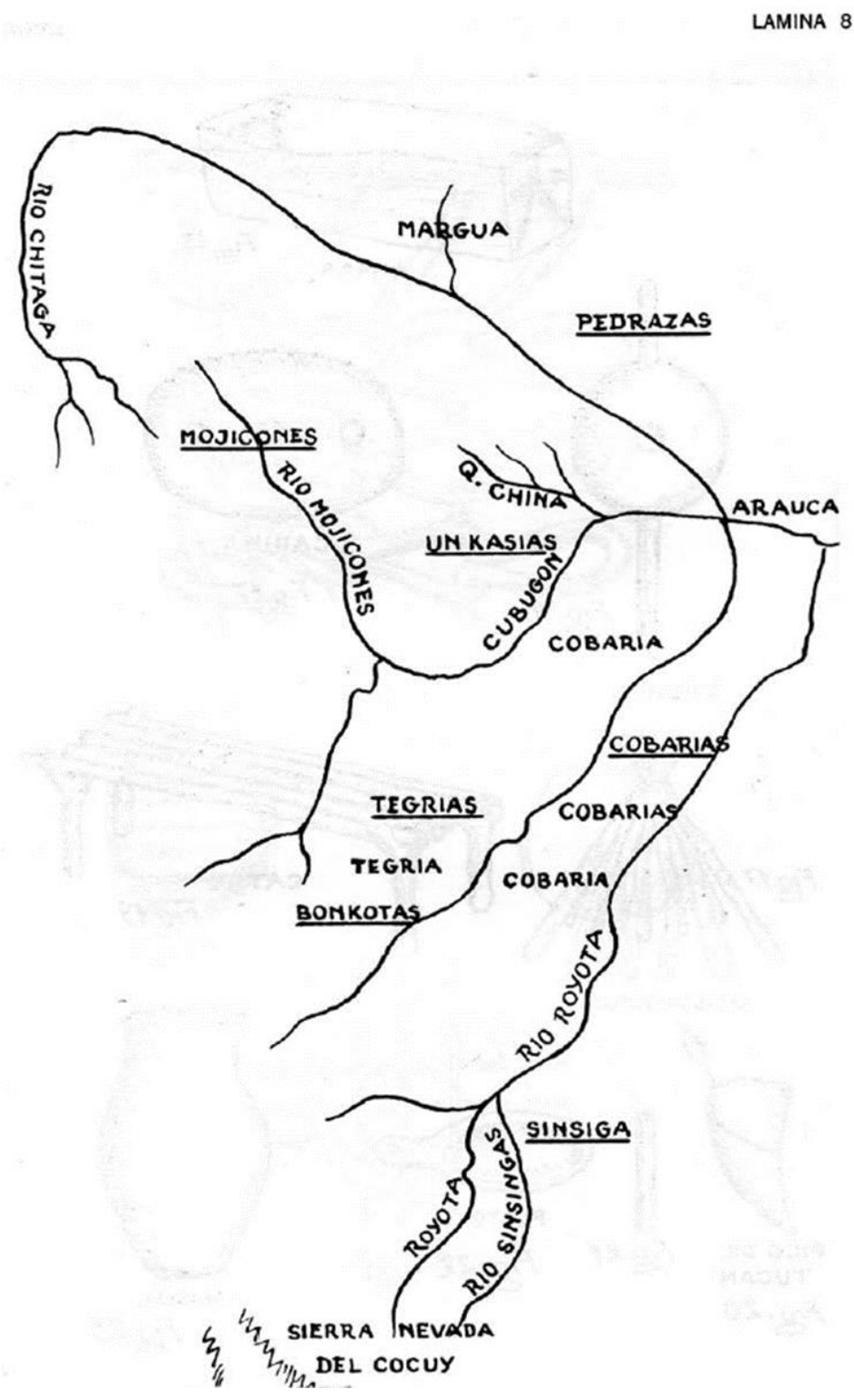

Figure 2. Map or scheme of the U'wa territory made by the French missionary Henri Rochereau, with data collected between 1914 and 1939. Source: Rochereau, 1961.

(Viasús-Figueredo et al. 2016) and is also incorporated into the different forms of representation of the communities that inhabit, travel, appropriate, conceptualize and express their territory on the basis the relationships established between the parts and the whole, just like the tissue that makes up a body. Hence, one of the archetypal indigenous representations is the body-territory, in which the latter is not visualized as a set of layers, polygons, lines, points, and vectors, as in the Western cartographic tradition, but as a living organism that feeds, reproduces, and establishes relationships with other beings (Echeverri, 2004).

This type of representation configures a particular cartographic language that may represent the territory (Figure 3) as a vital element for the U'wa people from the perspective of a traditional doctor
(ASOU'WA, 2019). This is a representation of the body-territory which emphasizes the existence of a profuse network, composed mainly of mountains and rivers, which connects the different parts of the body, in particular the upper and lower extremities and the head. This representation corresponds to the model of the universe found in the U'wa cosmology, in which biotic and abiotic aspects of the landscape, such as rivers and mountains, take on special relevance and stand as ordering axes of the territories of the different clans (Serje, 2011). However, from a non-indigenous perspective this representation is difficult to understand since it does not follow the conventional parameters of cartographic representation. Therefore, the bodily figure which serves as a cosmography or representation of the U'wa universe accounts for the existence of another possible territory in which all elements are interconnected and function 
in a coordinated way to stay active and sustain themselves: the mountain ranges irrigate the whole body, generating the sensation of movement that enlivens a network of places that, through their relationality, configure a territory of difference (Escobar, 2010).
The territory of the U'wa people is a living organism that transcends the notion of land as a geographical space that might be allotted to a community in accordance with agrarian criteria exclusively and ignoring the indigenous productive and socio-cultural system

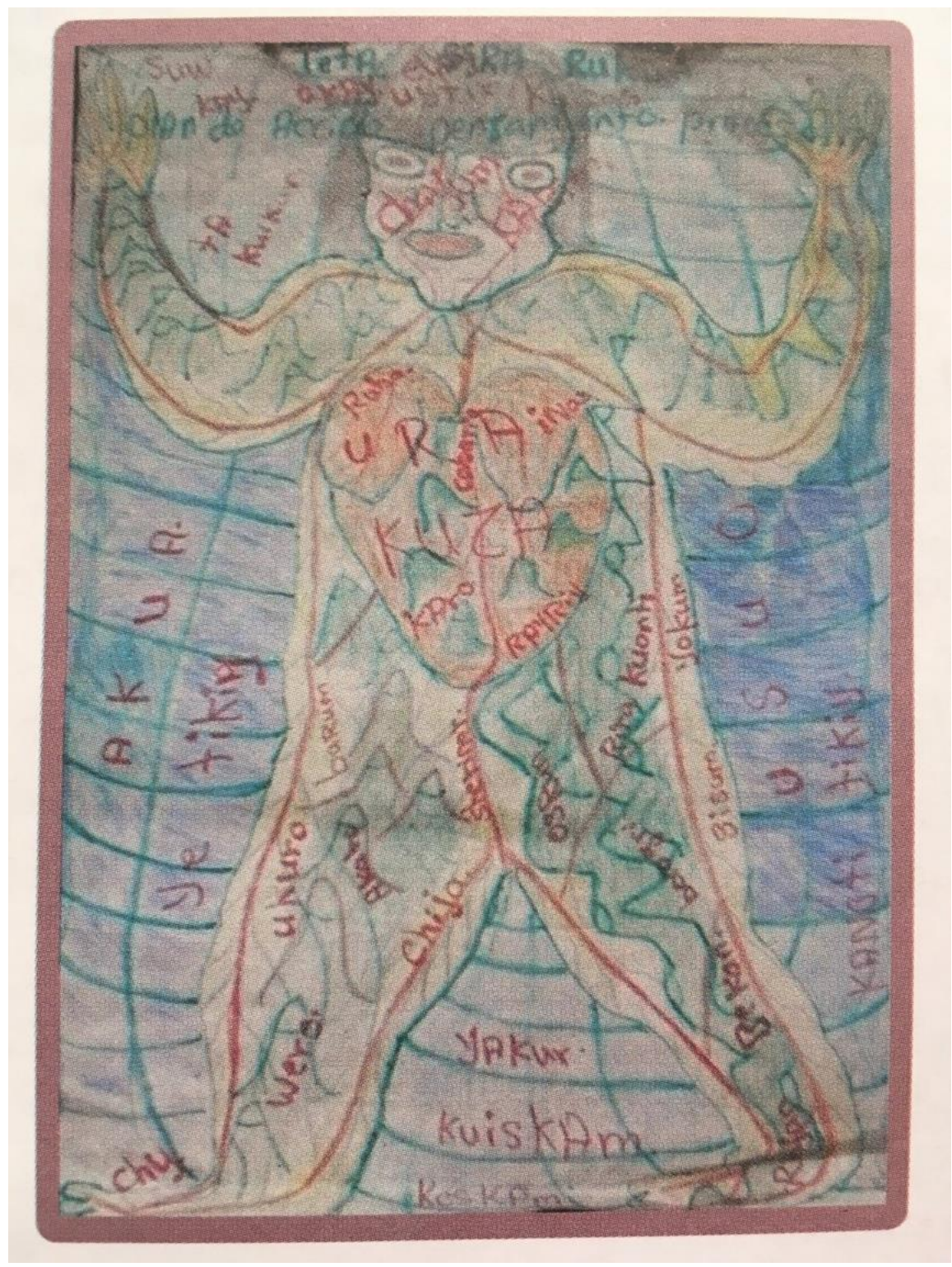

Figure 3. The U'wa territory represented as a body by a traditional U'wa physician, Rúbico Cobaría. Source: AsoU'wa, 2019.

itself (Balza, 2001); such a territory ought to be simultaneously appropriated, understood, and represented, both materially and symbolically, in biophysical terms (emphasizing the interaction and mutual determination of the communities and the inhabited environment) and epistemic terms (emphasizing the systems of native knowledge and know-how in contrast with those of the modern and colonial western world). Regarding this point, figure 3 shows the process of sociocultural appropriation of nature and ecosystems from the point of view of the U'wa native relational worldview or ontology (Escobar, 2014). However, this cosmographic representation of the U'wa world, understood as body-territory is complemented by other types of representations that account based on the daily experience of living, in which the dimension of the landscape stands out as a result of the perception of some members of the community.

As an example of the above, figure 4 shows a mural made by the students of the Indigenous Educational Institution "Escuela 
Internado El Chuscal"-located in the rural area of the municipality of Cubará- which represents a bee as part of the landscape and in the foreground. The bee, or "anuba" in the uw'ajka language, is an insect of cultural and ritual importance. According to the culture and worldview of the different communities, this insect is a reflection of their practices: like the U'wa, bees are seen as highly social creatures who build houses or beehives and have songs, dances, and ceremonies where ingest beverages prepared with their saliva, honey in the case of bees and corn chicha in the case of the U'wa chicha (Osborn, 1995). In addition to this type of representations and forms of symbolic appropriation of the territory, the U'wa people have the sung myths of their oral geography, an essential aspect of the traditional ceremonies and dances celebrated by the communities throughout the year, in accordance with their calendar of rituals and harvests.

Based on these representations of the territory, the U'wa have built a particular language through a sung geography that accounts for ancestral spaces and places, and this has perpetuated not only their wisdom but also elements and references of territoriality such as the stove, the swidden, the forest, the mountains, and the rivers (ASOU'WA, 2019). Although the indigenous people do not appear in the representations, they perceive themselves as a component of the whole of which they are part, in a holistic relationship with other living beings, plants, and animals (Vásquez \& Verschoor, 2011). This principle of relationality is constitutive of and indigenous territoriality that, by means of exchanges of different nature, links the multiplicity of life trajectories of non-indigenous living beings, deities, and human beings. One type of exchange occurs with the dialogue and collective construction of knowledge about the territory between external researchers and the educators of the U'wa people. Their relationship was founded on horizontality to promote mutual recognition as subjects of enunciation with a life history, a point of view, and a voice of their own that should be more significant than the claim to scientific objectivity, given the skepticism of indigenous communities in the face of epistemic extractive practices that seek to take their ideas as raw materials to colonize and subsume them under the parameters of culture and the Western episteme (Grosfoguel, 2016).

This position was observed in the ethnoeducators of the U'wa people, and it can be interpreted as a practical exercise of territoriality, since it is configured as an alternative to manage and solve their spatial requirements and claim their territory (Balza, 2001), for which they engage in a constant struggle based on a deep understanding of life and its cosmogony as part of a pluriverse made up of an ever-changing network of relationships between human and nonhuman beings, which, despite Western domination over "nature"

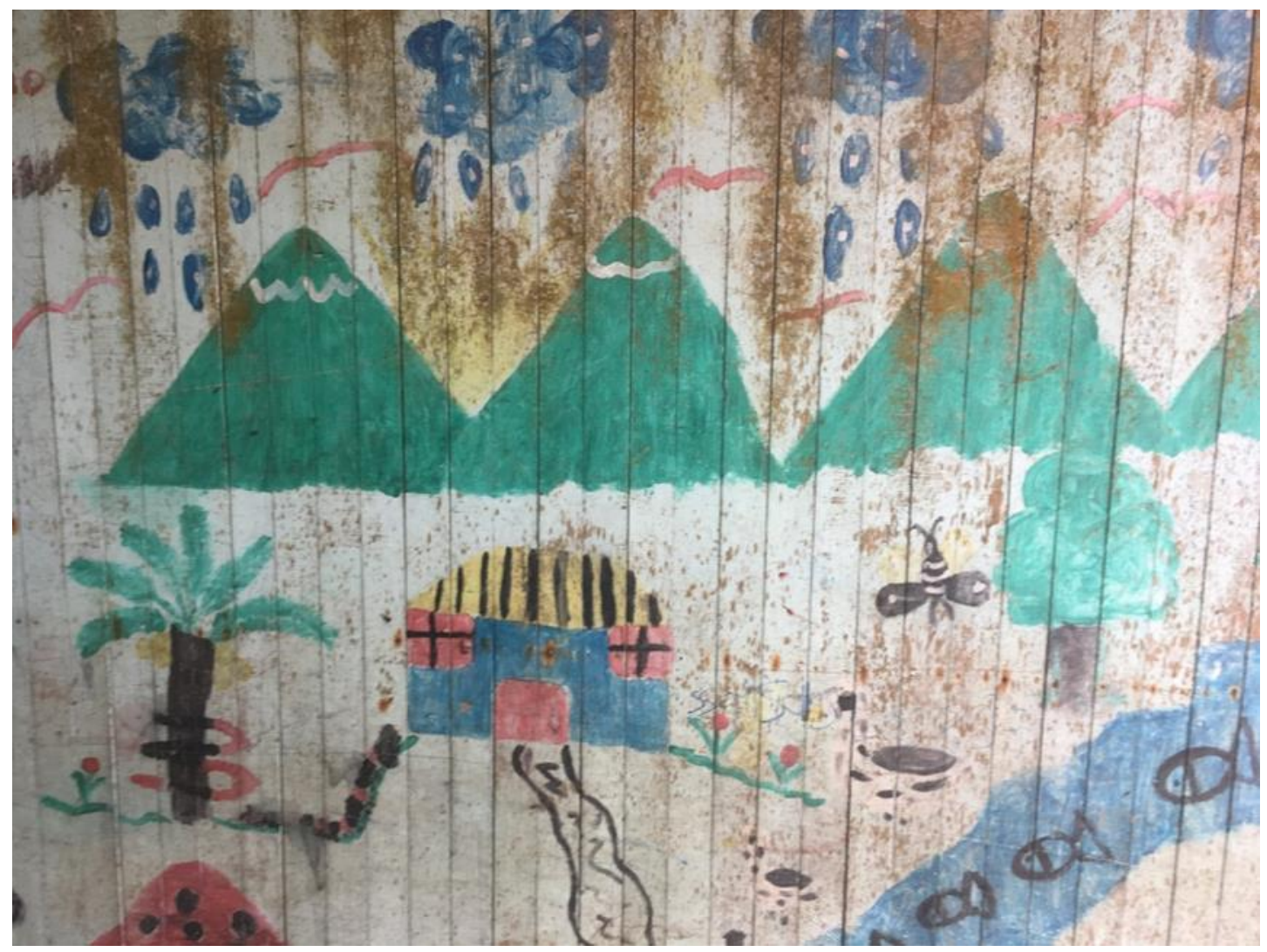

Figure 4. Representation of the U'wa landscape by a student from the El Chuscal Boarding School, together with details of what appears to be a bee ("anuba"), an insect of cultural and ritual importance for the U'wa. Source: Oscar Gamba Archive, 2017. 
on account of the exploitation caused by the capitalist production system, is not necessarily determined by the superiority of one over the other (Escobar, 2012; Escobar, 2014). Thus, understanding the territory of the U'wa people implied incorporating the dimension of social and power relations to deconstruct and denature a good part of the traditional precepts and approaches (Altschuler, 2013) generated by external discourses. The review of these sources and its contrast to some materials published by the communities themselves as well as their practices of appropriation of space- led to the conclusion that in relation to the conventions of Western cartography and disciplines such as anthropology or linguistics, the great complexity of elements that make up the landscape and the U'wa territory appear only as ordering axes of space, like limits or natural markers alien to a process of humanization and social and historical transformation, since they are emptied of the deep cosmological meaning of the native communities.

\section{Closing Remarks and Conclusion: From Territoriality to} Feeling and Thinking the Ethno-territory. The joint research that was undertaken managed to test an alternative way to think about the territory based on the Participative and Active Research [Investigación Acción Participativa] methodology, which tries to blur the distinction between researchers and research subjects and rewrite history from below using novel and controversial formats (Robles \& Rappaport, 2018), so that the common people may know more about their vital conditions to defend their interests against those who have monopolized knowledge, resources, techniques, and power itself (Fals Borda, 1999). This perspective allows the generation of a holistic epistemology that conceives researchers and research subjects, not as experts and clients, but as sentient beings whose diverse points of view on cohabitation must be considered side by side in order to balance the production of conscious knowledge since reason is enriched with the feeling, so that the head and the heart work together to co-reason or feel-think (Fals Borda, 1999; Escobar, 2014).

Recognizing that indigenous people feel and think with the land allowed us to understand that a cultural territory inhabited by an ethnolinguistic group such as the U'wa is configured as an ethnoterritory, that is, a historical, cultural and, identity territory that is recognized as their own, since it provides more than a dwelling place, sustenance, and reproduction as a group: it provides the opportunity to reproduce culture and social practices over time (Barabas, 2008). As a place where the history of the U'wa people takes shape, it was possible to interpret the landscapes and spaces that make up the territory as appropriate from the cultural point of view, emphasizing aspects such as the worldview or history of the community. From this point of view, it must be taken into account that the territory is a memory space, as well as a receptacle that mobilizes complex symbolic and mythological senses through entities such as bodies of water, lakes, lagoons, or mountains. In the case of the U'wa territory, the exploration of all these forms of appropriation and assignment of meanings to the inhabited space by the communities appears as one of the possible paths to understand the territoriality of these indigenous people in all its complexity.
Acknowledgments: This work was made possible by the accompaniment, collaboration, and permanent guidance of the teachers of the United U'wa Reservation, particularly the coordinator of the indigenous educational centers, Professor Elizabeth Tarazona Cobaría. We are grateful to her and the entire teaching team of the municipality of Cubará, Boyacá, for allowing us to visit part of its territory, and we express the most sincere feeling of admiration for the important work that is carried out day by day to educate an entire people without forgetting what is native. Conflict of interests: The manuscript was prepared and reviewed by all the authors, who declared that no conflict of interest may put the validity of the results presented at risk. Financing: This article is the product of the research entitled "Inhabiting and Narrating the Territory: Tools to Strengthen the Ethno-educational Project of the U'wa People, Kajkrasa Ruyina”, funded by the Pedagogical and Technological University of Colombia -UPTC-.

\section{REFERENCES}

1. ALTSCHULER, B. 2013. Territorio y desarrollo: aportes de la geografía y otras disciplinas para repensarlos. Theomai. (Argentina). 27-28:64-79.

2. ASOCIACIÓN DE AUTORIDADES Y CABILDOS U'WA, ASOU'WA. 2014. Plan de Salvaguarda Nación U'wa Kera Chikara Obiryacquinacu, AsoU’wa. (Colombia). 167p.

3. ASOCIACIÓN DE AUTORIDADES Y CABILDOS U'WA, ASOU'WA. 2019. Proyecto Educativo Comunitario. Institución Educativa Técnica Ambiental Kera Shikara; Fondo Editorial Asou'wa (Colombia).

4. BALZA, R. 2001. Tierra, territorio y territorialidad indígena: un estudio antropológico sobre la evolución del espacio del pueblo indígena chiquitano de la ex-reducción jesuita de San José. Apoyo para el Campesino Indígena del Oriente Boliviano; Grupo Internacional de Trabajo sobre Asuntos Indígenas; Servicio Holandés de Cooperación al Desarrollo. (Bolivia). 356p.

5. BARABAS, A. 2008. Cosmovisiones y etnoterritorialidad en las culturas indígenas de Oaxaca. Antípoda. Rev. Antropología y Arqueología. (Colombia). 7:119-139.

6. CARVAJAL, N. 2011. Enfoques ascendente y descendente del ordenamiento territorial en Colombia. Cuadernos de Geografía: Rev. Col. Geografía. 20(1):21-28. https://dx.doi.org/10.15446/rcdg.v20n1.23064

7. CHAVES, A. 1974. Los tunebos: datos etnográficos. Universitas Humanística. (Colombia). 8-9:9-75.

8. CORREA, F. 2004. El sol del poder: simbología y política entre los muiscas del norte de Los Andes. Universidad Nacional de Colombia. 420p. 
9. ECHEVERRI, J. 2004. Territorio como cuerpo y territorio como naturaleza: ¿diálogo intercultural? En: Surrallés, A.; García, P. (dir.). Tierra adentro: territorio indígena y percepción del entorno. Grupo Internacional de Trabajo sobre Asuntos Indígenas. (Copenhague). p.259-275.

10. ESCOBAR, A. 2010. Territorios de diferencia: lugar, movimientos, vida, redes. Envión Editores (Colombia). 386p.

11. ESCOBAR, A. 2012. Más allá del desarrollo: postdesarrollo y transiciones hacia el pluriverso. Rev. Antropología Social. (España). 21:23-62.

https://doi.org/10.5209/rev_RASO.2012.v21.40049

12. ESCOBAR, A. 2014. Sentipensar con la tierra: nuevas lecturas sobre desarrollo, territorio y diferencia. Universidad Autónoma Latinoamericana. (Colombia). 184p.

13. FALCHETTI, A. 2003. La búsqueda del equilibrio: los Uwa y la defensa de su territorio sagrado en tiempos coloniales. Acad. Col. Historia. 268p.

14. FALS BORDA, O. 1999. Orígenes universales y retos actuales de la IAP. Análisis Político. (Colombia). 38:73-90.

15. FLÓREZ, A. 1991. La sierra nevada del Cocuy, Chita o Guicán. EPG-Geografía. (Colombia). 1(2):7-18.

16. GARCÍA, J. 1976. Antropología del territorio. Taller de Ediciones Josefina Betancor. (España). 350p.

17. GROSFOGUEL, R. 2016. Del “extractivismo económico” al "extractivismo epistémico" y al "extractivismo ontológico": una forma destructiva de conocer, ser y estar en el mundo. Tabula Rasa. (Colombia). 24:123-143. https:/ /dx.doi.org/10.25058/20112742.60

18. HEADLAND, E. 1997. Diccionario Bilingüe. Uw Cuwa (Tunebo) - Español. Español - Uw Cuwa (Tunebo), con una gramática uw cuwa (tuneba). Instituto Lingüístico de Verano. (Colombia). 286p.

19. MÁRQUEZ, M. 1981. Los indios Tunebo y su cosmogonía. Universidad Católica Andrés Bello. (Venezuela). 189p.

20. MÁRQUEZ, M. 1983. Trascendencia ideológica de los Tunebo. Ed. Copymundo (Colombia). 100p.

21. MÁRQUEZ, M.; AGUABLANCA, E.; OLZA, J. 1988. Gramática de la lengua tuneba: morfosintaxis del cobaría. Universidad Católica del Táchira. (Venezuela). 240p.

22. OSBORN, A. 1985. El vuelo de las tijeretas. Banco de la República (Colombia). 153p.
23. OSBORN, A. 1995. Las cuatro estaciones: mitología y estructura social entre los U’wa. Banco de la República. (Colombia). 269p.

24. PRADILLA, H. 1978. Tunebia infiel: la persecución religiosa a los Tunebo. Universidad Nacional de Colombia. 51p.

25. RIAÑO, E. 2003. Organizando su espacio, construyendo su territorio: transformaciones de los asentamientos Ticuna en la ribera del Amazonas colombiano. Universidad Nacional de Colombia. 236p.

26. RIVET, P. 1924. La langue Tunebo. J. Société des Américanistes. (Francia). 16:19-92. https://dx.doi.org/10.3406/jsa.1924.3758

27. ROBLES, J.; RAPPAPOR'T, J. 2018. Imagining Latin American social science from the global south: Orlando Fals Borda and participatory action research. Latin American Res. Review (Estados Unidos). 53(3):597-612. http://dx.doi.org/10.25222/larr.164

28. ROCHEREAU, H. 1914. Los indios tunebos: relación de la misión científica de 1914 del P. Rochereau, Dr. R. Monsalve y Néstor Parra. Boletín de Ciencias Naturales del Instituto de La Salle. (Colombia). 2(7):195-197.

29. ROCHEREAU, H. 1926. La lengua tuneba y sus dialectos: ensayo gramatical. Diócesis de Pamplona. (Colombia). 101p.

30. ROCHEREAU, H. 1961. Los tunebos: grupo unkasia. Rev. Col. Antropología. 10:37-120.

31. SERJE, M. 2011. El revés de la nación: territorios salvajes, fronteras y tierras de nadie. Universidad de los Andes. (Colombia). 368p.

32. VALENZUELA, C.; FIGUEROA, M. 2012. Implicancias de la resignificación de la espacialidad en las categorías de análisis geográfico: la revalorización del territorio como constructo social. Perspectiva Geográfica. (Colombia). 17:49-70. https://dx.doi.org/10.19053/01233769.2262

33. VÁSQUEZ, J.; VERSCHOOR, G. 2011. En defensa de lo propio: hacia el perfeccionamiento de las relaciones entre el mundo Tikuna y el mundo occidental. Wageningen University; Small World Foundation; Tropenbos Internacional. (Colombia). 79p.

34. VIASÚS FIGUEREDO, L.R.; POSADA ARRUBLA, A.; DÍAZ PERDOMO, H.J. 2016. Ordenando el territorio: entre el camino de los ancestros y la perspectiva contemporánea. Caso comunidad indígena Muisca de Bosa, Bogotá Colombia. Prospectiva: Rev. Trabajo Social e Intervención Social. (Colombia). 22:141-171. https://dx.doi.org/10.25100/prts.v0i22.1240 